$(200)$

Cold has

VIS. 63

SECTIOI

ATION

COMPII

RESO urréti

TEM -63

Geological Survey $/ 4000008$ Experimental Drilling in Chattanooga Shale.

Andrew Brown

July 2, 1948

Jase I tarking

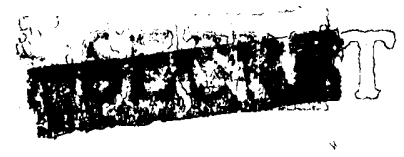

TERTSBSBSAT 



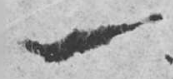

Dr. Ph11.1p I. Nemitt,

v. S. Atorde Energy Commission,

P. 0. Oox 30, Ansonia Station,

New York 23, Nev York.

Dear Dr. Nerritt:

In accordance with a recent oral request recelved by Watson $\mathrm{H}$. Honrce from $\mathrm{B}$. B. Thurlow, of your office, a report "Iixperimental Driliting in Chat anooga Shale" by Andrew Brown, is tranenitted herevith, in duplieate, for your information and flles.

As indicated in the report, experience to date in driling the Chattanooga shale has ahown that Inereaging the hole size to 3 inches resulted in better cores and better core recoveries than were obtained with the "Lu and "rox" holes.

\section{Sincerely youra,}

Thomas B. Nolan, Assístant Director.

Encl nsure 377.

ce: Thurlow

Black Shale

Monroe reading

AEC Chron.

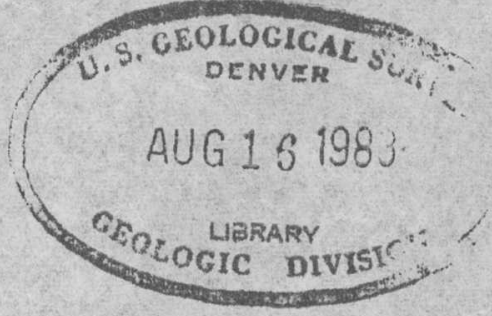

HDK : $k I g$ 
EXPERTIENTAI, DRTTIING IN GHATTANOOGA STATE

BY

USC JAESH LID Andrew Brown
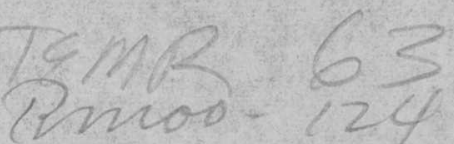

Information on which specifications were originally drawn for drilling the Chattanooga shale was obtained largely from the TVA, whose geologists and drillers laid great stress on the diffioulties of maintaining circulation in their holes. They stated that the shale itself was not particularly difficult to core, the trouble being in the overburden. They did not use deep casing, depending on cementing to hold the holes open. On this basis, the Survey's spectfications called for mid casing only, it being assumed that solid rock would be encountered at relatively shallow depths. This belief was borne out by examination of such road cuts and other exposures as were available.

The first hole drilled by the Survey LC-101, seemed to bear out the TVA's experience in that the hole struck an underground stream which could not be entirely blocked off. However, there was some water return, and the hole could probably have been cored if the drillers had not lost a bit which they could not recover. The second hole, IC-102, was on a saddle in a long ridge and encountered no circulation troubles other than a slight tendency to lose water along bedding planes, which was overcome by drilling with heavy wd and by cementing at one point. Hole IC-103, on the plateau several miles from any outcrop, showed the same drilling characteristics. In all these holes a tendency to cave was noted in the top 60 to 80 feet, but the heavy drilling mud made it possible to obtain fairly good cores.

The next two holes, however - LG-104 in a creek bottom, and LC-105 on the plateau, gave so mich trouble from caving that even cementing was ineffective. Some core was obtained from $\mathrm{LC}-104$, but it was unsatisfactory; and in attempting to clean $\mathrm{LC}-105$ preparatory to coring, a bit was twisted off and the hole lost by the contractor. It is now being redrilled.

\section{Experience on these first holes showed:}

1. Solid rock, instead of being near the surface, is from 60 to 80 feet deep; this top 60 to 80 feet being composed of broken chert, soil, and some solid ledges of cherty limestone. (Fort Payne formation)

2. Circulation difficulties, such as cavities, etc., are not as serious as the TVA's experience indicated. The explanation probably is that the TVA drilled mostly in stream bottoms (particularly at the Great Falls dam, for grouting purposes), whereas the Survey's holes are mostly on high land.

3. Drilling with heavy mud, and cementing at weak places in the holes, will maintain circulation and keep the hole open fairly well in about half the holes drilled; but even in these some material invariably fell into the hole from the broken material near the top, resulting in damage to core bits, and adding to the difficulty of coring, in general.

Considering the observations atove, it was decided that most of the circulation difficulties would be met in the top 60 to 80 feet of the hole, and that the only dependable way to keep that part open was by casing. Any cavities that exist in the solid Fort Payne are probably small, and can be held be cementing. For this reason, a change in the contract calling for deep casing was requested. 
It can be seen that all drilling done so far has been in a measure experimental, the two problems to be solved being (1) keeping the hole open and (2) the actual coring. The first appears to be well in hand, the principal difficulty being the slowness of the drilling due to the hard Fort Payne, and the difficulty of the cortractor in keeping sufficient bits on hand. The coring itself will now be discussed.

The Chattanooga shale is relatively soft, but on the other hand is extremely tough and broken by numerous joints which give much trouble. Cores from LC-102 and LC-103 showed more than 90 percent recovery and were adequate for sampling purposes, though not for stratigraphic information. Few pieces were more than half a foot long, and much of the core was in the form of disks much like poker chips. In view of this condition, another check was made with the TVA, and it was found that the shale which had cored was the Athens shale, which is much more calcareous than the Chattanooga and that at the one poini they tried to core the Chattanooga (New Johnsonville) they failed completely and gave up the attempt, attributing their failure to a combination of difficulty in keepine the holes clean, and the brittleness of the shale itself. Following this conference, and the loss by the contractor of hole IG-105, the drill was taken to Wrights Bend in Caney Fork River bottom for coming experiments. It should be said that it was desired to drill that locality two months before it was done, but the condition of the trail to the bottom was such that it could not be used until the ground dried.

Four holes were drilled at Wrights Bend, the surface there being within a few feet of the top of the Chattanooga. It was expected that the shale would be in bad condition; it was more weathered than anticipated. In addition, a brecciated zone about 3 feet thick was encountered at the bottom, which was not recovered. The first hole, LC-108, was drilled with heavy mud and cemented. After 8.9 feet had been cored with a 3 -inch barrel with a recovery of 6.9 , the hole caved and was abandoned. The second hole, LC-108-A, was cased to 23 feet, fishtailed to 25.5 feet, and cored to the underlying limestone at 34.3. Thus 8.8 feet were cored, recovery being 5.8 feet; but the bottom run of 2.5 feet, in the brecclated zone was lost completely, so the recovery for the upper part was 5.8 out of 6.3 which, considering the weathered condition of the shale, was better than hoped for. Hole LC-108-AA was then drilled at an elevation 5 feet higher than LC-108-A, cased to 23 feet, and cored for 8.3 with a recovery of 6.8 feet.

Hole LC-108-B was then drilled alongside LC-108-AA, cased to 23 feet, and cored with an "N" (2-inch) core barrel. Of the 15.5 feet cored, recovery was only 3.7 feet, or 24 percent, this despite the fact that the bit and lifter used on this hole were better adapted for the work than those on the 3 -inch barrel.

Experience with the 108-series holes confimed opinions which had been formed during earliex drilling; that because of the brittleness of the shale, and its numerous bedding planes and joints, both core recovery and the condition of the core improved with its size. Previously, holes LC-102 and IE-103, cored with "NX" (2 I/g") bits, gave fair recovery, whereas holes LC-104 and IC-108*B cored with 2-inch bits, were distinctly unsatisfactory. This comparison is not entirely accurate, because the shale in the two last-named holes was more weathered than that in the first two; but in any event it was plain to anyone who examined the cores that the $1 / 8$ " difference between the "N" and the "NX" sizes made a remarkable difference in recovery and in core condition. When 
che size was increased to 3 inches recovery was about the same as in the . "NX" holes, but the core was in much longer pieces and in far better condition generaliy. This in spite of the fact that the $3-i n c h$ cores were taken in weathered rock, and that both the bit and the core-lifters used were not of the best type. They have been improved and future results should be much better.

Another feature which showld help recovery is based on observations In the 108-series of holes. On the drill in use here, the vater pump is geared to the drilling speed. As core bits should be run rapidly, this means that a large amount of water runs through the barrel during coring. Undoubtedly this heavy water pressure breaks up the core to some extent. Therefore, a separate pump transmission is being installed on the drill, which will make it poscible to run coring bits at high speed but with low water pressure.

The request for a change from "N" or "NX" cores to 3 -inch was made on the basis of the expexience outlined above, which showed that the larger size gave considerably better recovery, and far better cores generally; they also give more than twice as much material for sampling purposes. The larger holes are a necessity if the nominal 3-inch core barrel is used; and the casing is the only metiod which holds promise of keeping the holes clean. If the holes can be kept clean, it will be possible to use diamond bits, which have been avoided so far because of the loose materlal falling into the bottom of the hole. However, hard-faced bits can take satisfactory cores in this material if handled properly. 